\title{
The influence of evapotranspiration on vertical flow subsurface constructed wetland performance
}

\author{
Andrzej Białowiec $^{\mathrm{a}, *}$, Antonio Albuquerque ${ }^{\mathrm{b}}$, Peter F. Randerson ${ }^{\mathrm{c}}$ \\ a Wrocław University of Environmental and Life Sciences, Faculty of Life Sciences and Technology, Institute of Agricultural Engineering, \\ 37/41 Chetmońskiego Str., 51-630 Wrocław, Poland \\ ${ }^{\mathrm{b}}$ Department of Civil Engineering and Architecture, University of Beira Interior, Edificio 2 das Engenharias, Calcada Fonte do Lameiro, \\ 6201-001 Covilha, Portugal \\ ' School of Biosciences, Cardiff University, Cardiff CF10 3AX, UK
}

\section{A R T I C L E I N F O}

\section{Article history:}

Received 7 November 2013

Received in revised form 13 January 2014

Accepted 25 March 2014

Available online 20 April 2014

\section{Keywords:}

Constructed wetlands

Evapotranspiration

Removal efficiency

Concentration

Mass balance

Water balance

\begin{abstract}
A B S T R A C T
This paper presents an example of the importance of evapotranspiration in constructed wetlands, with vertical subsurface flow, comparing different methods of treatment efficiency calculations and discussing the influence of evapotranspiration on removal rates. The application of reed, marked by high transpiration ability, is a cheap and effective method of landfill leachate disposal. A 2-year study examined the effectiveness of leachate treatment in constructed wetlands with reed. Two kinds of vertical subsurface flow systems: first with sand, and second with combined two layers of sewage sludge and sand has been tested. 1,3 , and $5 \mathrm{~mm} \mathrm{~d}^{-1}$ hydraulic loading rates of landfill leachate have been applied. Daily evapotranspiration was in the range from 0.98 to $2.99 \mathrm{~mm} \mathrm{~d}^{-1}$ in the first year of research and from 2.56 to $4.61 \mathrm{~mm} \mathrm{~d}^{-1}$ in the second year. The influence of evapotranspiration rate on chemical oxygen demand (COD) removal rate was examined. Two methods of removal efficiency calculation have been used: first based on inlet and outlet COD concentrations, second on mass balance determination. Research showed that the removal efficiency calculated as a comparison between initial and final concentration is significantly lower, than expected from mass balance, especially, when higher hydraulic loading rates were applied.
\end{abstract}

(C) 2014 Elsevier B.V. All rights reserved.

\section{Introduction}

The use of ecological systems such as constructed wetlands (CWs), is recognized as an economical and technically sustainable solution for wastewater treatment making it safe to discharge into the environment. CWs are artificial complexes of water, matrix, vegetation and the associated invertebrate and microbial communities designed to simulate the ability of natural wetlands to remove pollutants from water (Brix, 1997), and are a good example of ecological engineering (Mitsch and Jorgensen, 2004). They provide an inexpensive and reliable method for treating a variety of wastewaters such as sewage, landfill leachate, mine leachate, urban storm-water, agricultural run-off, are very efficient for nutrient removal (Białowiec et al., 2011; Lu and Huang, 2010) are

\footnotetext{
* Corresponding author. Tel.: +48 609681877; fax: +48 609681877

E-mail addresses: andrzej.bialowiec@up.wroc.pl, bialowiec@gmail.com (A. Białowiec), ajca@ubi.pt (A. Albuquerque),randerson@cardiff.ac.uk (P.F. Randerson).
}

comparatively simple to construct, operate and maintain (Kadlec and Wallace, 2008; Randerson, 2006), and are suitable for advanced and polishing treatment if water reuse is an option (Marecos do Monte and Albuquerque, 2010; Masi and Martinuzzib, 2007; Pedrero et al., 2011).

Plants commonly used in constructed wetlands include: cattail (Typha latifolia L.), reed (Phragmites australis Trin ex Steudel), rush (Juncus effusus L.), yellow flag (Iris pseudacorus L.), mannagrass (Glyceria maxima), and giant reed (Arundo donax L.). As well as these typical natural wetland plant species, willow (Salix sp.), may be used in CWs with high efficiency (Aronsson and Perttu, 2001; Perttu and Kowalik, 1997).

Willows have been used in the treatment of agricultural runoff and leachate from landfill sites (Białowiec et al., 2007; Duggan, 2005), and are especially successful at removing high levels of ammonia and nitrogen from solution. Willow treatment systems also can achieve zero discharge of water due to evapotranspiration (ET), and part of the nutrients can be recycled via the plant biomass (Białowiec et al., 2011; Vymazal and Kropfelova, 2008). Some wetland species, such as reed, are tolerant of moderately high salinity 